www.jmscr.igmpublication.org

Index Copernicus Value: 79.54

ISSN (e)-2347-176x ISSN (p) 2455-0450

crossref DOI: https://dx.doi.org/10.18535/jmscr/v7i3.238

Journal Of Medical Science And Clinical Research

IGM Publication

An official Publication of IGM Publication

\title{
Evaluation of Intubating Condition using Propofol and Propofol Plus Sevoflurane: A Randomized Controlled Trial
}

\author{
Authors \\ Pradipta Kumar Patel $^{1}$, Sumati Kandi ${ }^{2}$, Ratikanta Nayak ${ }^{3}$, Saransh Mishra \\ ${ }^{1}$ Associate Professor, Department of Anaesthesiology, VIMSAR, Burla \\ ${ }^{2}$ Assistant Professor, Department of Anaesthesiology, VIMSAR, Burla \\ 3,4Junior Resident, Department of Anaesthesiology, VIMSAR, Burla
}

\begin{abstract}
Background and Aims: The purpose of the present study was

1) To study and compare the ease of intubation with combination of Sevoflurane $4 \%$ and Propofol $1.5 \mathrm{mg} / \mathrm{kg}$ with IV Propofol $3 \mathrm{mg} / \mathrm{kg}$ alone.

2) To study the quality of intubation at first attempt.

3) To study the hemodynamic response during induction and intubation
\end{abstract}

Materials and Methods: The study was conducted in 80pts of ASA I \& II, non obese, adult patients aged between 20-40yrs coming for elective surgical procedures under General Anaesthesia. Anaesthesia was induced in Group A patients by $67 \% \mathrm{~N}_{2} \mathrm{O}$ in $\mathrm{O}_{2}$ and IV propofo $3 \mathrm{mg} / \mathrm{kg}$ injected over 30s. Group B patients were induced by mask with sevoflurane starting at $0.5 \%$ and incrementally increased to $4 \%$ inhaled concentration with $67 \%$ nitrous oxide in oxygen at a total gas flow of 8 liters $/ \mathrm{min}$ and IV propofol $1.5 \mathrm{mg} / \mathrm{kg}$ injected over $15 \mathrm{~s}$ and tracheal intubation was attempted at 240 s after the start of induction in both groups. The heart rate, systolic blood pressure, diastolic blood pressure and mean arterial pressure before and after induction and post-intubation at 1, 3 and 5 minutes were recorded. Intubating conditions were assessed by anaesthesiologist who performed intubation using Copenhagen Consensus Conference $(C C C)^{18}$ intubation score.

Results: Overall acceptable intubating conditions were significantly associated with Group B when compared with Group A. Number of attempts were significantly less in Group B when compared to Group A.

Conclusion: We concluded that combination of inhalational 4\% sevoflurane with IV propofol $1.5 \mathrm{mg} / \mathrm{kg}$ is superior to IV propofol $3 \mathrm{mg} / \mathrm{kg}$ with respect to quality of intubation and less significance with respect to hemodynamic response during induction and intubation in adult patients undergoing various elective surgical procedures without muscle relaxants and also this combination is cost effective.

Keywords: Propofol, Sevoflurane, Copenhagen Consensus Conference intubation (CCC)Score.

\section{Introduction}

Airway management is a fundamental aspect of anaesthetic practice and of emergency and critical care medicine. Endotracheal intubation (ETI) is a rapid, simple, safe and non surgical technique that achieves all the goals of airway management, namely, maintains airway patency, protects the lungs from aspiration and permits leak free ventilation during mechanical ventilation, and remains the gold standard procedure for airway 
management.

Insufflation of the trachea for the purpose of ether anaesthesia was introduced in 1909 in USA and in 1912 in UK ${ }^{1}$.

Neuromuscular blocking agents which aid tracheal intubation were first introduced into the clinical practice in 1942 in USA $^{1}$. The neuromuscular blocking agents have made technique of endotracheal intubation much easier, but not without the risks of subjecting the patient to potential risks. Until early 1990, suxamethonium was the only drug which was used for facilitating tracheal intubation due to its rapid onset and ultra short duration of action, but it has many potential side effects like myalgia, elevated intraocular and intracranial pressures, hyperkalemia, prolonged apnea, masseter spasm and malignant hyperthermia ${ }^{2-4}$. In United States (1993), the FDA has advised that suxamethonium be contraindicated for routine use in children and adolescents ${ }^{2-5}$. This justification was made due to the increased incidence of fatal or near fatal cardiac arrest in children who had received suxamethonium.

Non-depolarizing, neuromuscular blocking agents are alternative, but are slower in onset and they have a prolonged neuromuscular blockade ${ }^{3}$ and also an inability to reverse the paralysis quickly if airway management via mask or tracheal intubation is not possible $e^{2-6}$. The excessive or unnecessary neuromuscular blockade contributes to awareness under general anaesthesia, residual paralysis and sometimes even allergic reactions ${ }^{7}$. So, avoiding muscle relaxants when they are not required for planned procedures, may prevent the complications of their use, misuse and antagonism. Due to these reasons, a method for providing good intubating conditions rapidly without using muscle relaxants has been sought.

Propofol is a short-acting intravenous anaesthetic with high lipid solubility and short elimination half-life. It has been reported to depress pharyngeal and laryngeal reactivity to a greater extent than equipotent doses of thiopental. ${ }^{8}$ However, propofol has been associated with several adverse effects, including hypotension, apnea, pain on injection, and excitatory patient movements. ${ }^{9}$ Pain on injection can be avoided if propofol is administered after inhalation induction of anaesthesia. Propofol is an appropriate intravenous anesthetic agent for rapid induction and suppression of airway reflexes.

Endotracheal intubation was usually performed under deep inhalation anaesthesia with ether. The same technique was continued with halothane and of late, sevoflurane is gaining attention. Sevoflurane with its relatively pleasant smell, low airway irritability and low blood-gas solubility allowing smooth and more rapid induction and recovery. sevoflurane is frequently used for intubation without muscle relaxants, mostly in children. ${ }^{10-12}$ It has also been used in adults alone or in combination with nitrous oxide for intubation without muscle relaxants ${ }^{13}$

Combination of lesser percentage of halothane with propofol has been studied and concluded that combination of inhalational agent and propofol is ideal for intubation in children. ${ }^{14}$ Sevoflurane $8 \%$ can be used as tracheal intubation. ${ }^{15,16}$ But it is not cost effective. Combination of Sevoflurane $8 \%$ and propofol $1.5 \mathrm{mg} / \mathrm{kg}$ has been tried for Laryngeal Mask Airway insertion. ${ }^{17}$ Induction of anaesthesia with a combination of lesser dose of propofol and lesser percentage of sevoflurane with opioid pre-medication may optimize the inserting conditions of endotracheal tube and decrease the side effects that may follow with propofol alone. ${ }^{17}$ Hence an attempt was made with a combination of lesser percentage of Sevoflurane with reduced dosage of Propofol for intubation with endotracheal tube to evaluate intubation conditions, hemodynamic response during induction and intubation and induction side effects without muscle relaxants in adult patients of age group 20-40yrs undergoing various elective surgical procedures.

\section{Material and Methods}

The clinical study was carried out in adult patients of age group between 20-40yrs posted for various 
elective surgeries at VSSIMSAR, Burla, Sambalpur.

The study population consists of 80 ASA I \& II, non-obese, adult patients aged between 20-40yrs coming for elective surgical procedures under General Anaesthesia and had Mallampatti class I, II airway anatomy.

After approval of the study by our institution ethical committee and obtaining patient's written informed consent, patients were randomized into two groups of 40 each i.e. Group A and Group B. Patients of either sex, between the age group of 20-40 years belonging to ASA grade I and II undergoing elective surgical procedures of 1 to 3 hours duration were included in the study. Patient refusal with a history or evidence of a difficult airway and malignant hyperthermia, Patients on MAO-inhibitors, Patients with previous history of allergy to volatile anaesthetics or Propofol, Patients with body mass index more than 1.5 times normal were excluded.

A thorough pre-anaesthetic evaluation was conducted on the day before surgery. Detailed history and physical examination was carried out in all patients. All relevant investigations were done. Nil per oral status for a minimum periods of $8 \mathrm{hrs}$ was advised.

On the day of surgery, after arrival of the patient to the operation theatre, pulse-oxymeter, ECG, and non-invasive blood pressure monitors were connected. The baseline heart rate, systolic blood pressure, diastolic blood pressure and mean arterial pressure were recorded A suitable intravenous line was secured and a slow I.V drip was started in all patients with lactated Ringer's solution. All patients were premedicated with IV fentanyl $2 \mu \mathrm{g} / \mathrm{kg}$ IV midazolam $0.05 \mathrm{mg} / \mathrm{kg} \& \mathrm{IV}$ Glycopyrrolate $0.2 \mathrm{mg} 5 \mathrm{~min}$ before induction.

All patients were pre-oxygenated with $100 \%$ O for 3 min. Anaesthesia was then induced in Group A patients by $67 \% \quad \mathrm{~N}_{2} \mathrm{O}$ in $\mathrm{O}_{2}$ and IV propofo 3 $\mathrm{mg} / \mathrm{kg}$ injected over 30s. Group B patients were induced by mask with sevoflurane starting at $0.5 \%$ and incrementally increased to $4 \%$ inhaled concentration with $67 \%$ nitrous oxide in oxygen at a total gas flow of 8 liters/min and IV propofol $1.5 \mathrm{mg} / \mathrm{kg}$ injected over $15 \mathrm{~s}$ and tracheal intubation was attempted at 240s after the start of induction in both groups. Lignocaine $0.2 \mathrm{mg} / \mathrm{kg}$ added to propofol to prevent pain on injection.

The heart rate, systolic blood pressure, diastolic blood pressure and mean arterial pressure before and after induction and post-intubation at 1, 3 and 5 minutes were recorded. Time to induction in seconds (start of anaesthetic until loss of eye lash reflex), induction side effects like breath holding, cough, excitatory movements, laryngospasm and others (bradycardia, hypoxia, hyperthermia, hypothermia and injection site pain) were noted. Tracheal intubation was performed using appropriately sized endo- tracheal tube. Intubating conditions were assessed by anaesthesiologist who performed intubation using Copenhagen Consensus Conference $(\mathrm{CCC})^{18}$ which graded the quality of tracheal intubation according to ease of laryngoscopy, position of the vocal cords, cough and movement of the limbs.

Table : 1 Copenhagen Consensus Conference (CCC) intubation score

\begin{tabular}{|lr|c|c|c|}
\hline \multicolumn{2}{|l|}{ Laryngoscopy } & Easy & Fair & Difficult \\
\hline $\begin{array}{l}\text { Vocal cord } \\
\text { position }\end{array}$ & Abducted & Intermediate & Closed \\
\hline $\begin{array}{l}\text { Vocal cord } \\
\text { movement }\end{array}$ & None & Moving & Closing \\
\hline Coughing & None & $\begin{array}{c}\text { Diaphragmatic } \\
\text { movement }\end{array}$ & Severe coughing \\
\hline $\begin{array}{l}\text { Quality } \\
\text { intubation }\end{array}$ & Excellent & Good & Poor \\
\hline
\end{tabular}

Excellent $=$ all scores excellent Clinically acceptable

Good = all scores excellent or good

Poor $=$ any score poor Clinically unacceptable

Intubations were Excellent, when there was easy laryngoscopy, abducted and immobile vocal cords, without any limb movements or coughing. Good, when the laryngoscopy was fair, intermediate position with moving vocal cords, with slight limb movements and diaphragmatic movements. Poor, when there was difficult laryngoscopy, closed vocal cords, with vigorous limb movements and severe cough.

When the trachea could not be intubated, IV succinylcholine $1.5 \mathrm{mg} / \mathrm{kg}$ was administered intravenously. Following tracheal intubation in all patients, the tracheal cuff was gently inflated after 
confirming the position of the endo-tracheal tube by auscultation of chest and capnography and anaesthesia was maintained on oxygen, nitrous oxide and sevoflurane for 5min, afterwards sevoflurane was discontinued and muscle relaxants were administered.

The following parameters were studied during the procedure.

Time to induction (seconds): start of anaesthetic until loss of eye lash reflex.

Induction side effects: Breath holding, cough, excitatory movements, laryngospasm and others like bradycardia, hypoxia, hyperthermia, hypothermia and injection site pain.

Quality of endotracheal intubation: based on Copenhagen Consensus conference (CCC) scoring system.

Number of attempts taken for successful endotracheal intubation.

Supplementation of endotracheal intubation with IV succinylcholine.

Change in heart rate, systolic blood pressure, diastolic blood pressure, and mean arterial pressure during induction and intubation.

The data generated was statistically analyzed by using microsoft excel 2007, SPSS ver $19 \&$ Graph pad Software. The tools employed for statistical analysis are:

Mean, Standard deviation, students $t$ test, Chisquare test.

The description of the data done in the form of mean \pm SD for quantitative data. For quantitative data Student's t-test was used to compare between two groups. The intubating conditions were given in percentage. Chi-square test was used for qualitative data.

Significant $\mathrm{p}<0.05$, Strongly significant $\mathrm{p}<$ 0.01 , Not significant $P>0.05$

Blood pressure and pulse rate were compared between the two groups, using student's test. We considered excellent and good conditions as acceptable whereas poor as non-acceptable. The Chi-square test was used to compare the intubation scores.

\section{Observation and Results}

All the patient parameters and the results from the two groups (group A and group B) were entered in the predesigned study proforma sheet. Intubating conditions were scored and haemodynamic parameters were noted. The observations were complied and the result were analysed statistically.

Table: 2 Age Distribution Among the Patient

\begin{tabular}{|c|c|c|c|}
\hline Age in Yrs & $\begin{array}{c}\text { Group } \\
\mathbf{A}(\mathrm{n}=\mathbf{4 0})\end{array}$ & $\begin{array}{c}\text { Group } \\
B(n=40)\end{array}$ & \\
\hline $20-29$ & $24(60 \%)$ & $26(65 \%)$ & P value \\
\hline $\begin{array}{c}\text { Mean } \pm \text { SD } \\
30-40\end{array}$ & $\begin{array}{c}28.52 \pm 5.39 \\
16(40 \%)\end{array}$ & $\begin{array}{c}28.35 \pm 5.68 \\
14(35 \%)\end{array}$ & 0.888 \\
\hline Total & 40 & 40 & \\
\hline
\end{tabular}

Age in the two groups were statistically analyzed by student unpaired t test and it was found that there was no statistical difference between the two groups ( $p>0.05)$ (Table-2,Figure-1)

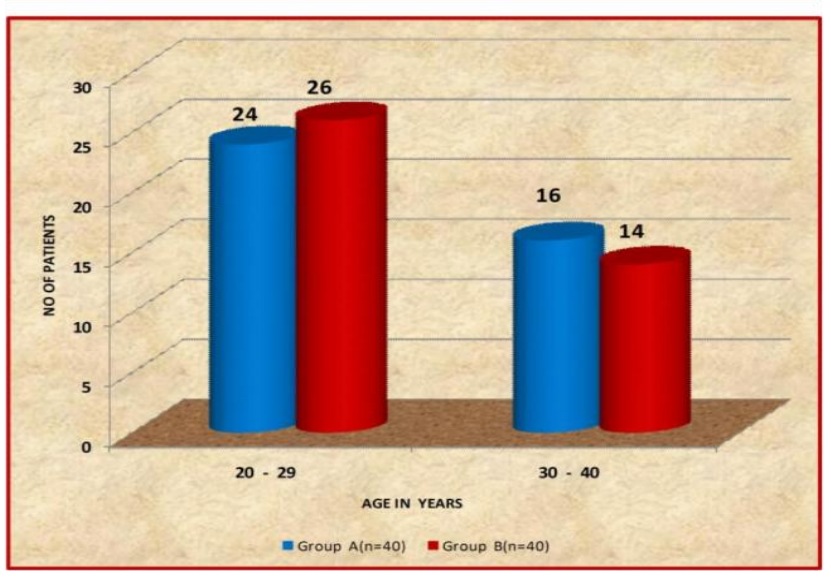

Figure 1 Age Distribution

Table: 3 Gender Distributions of Patients Studied

\begin{tabular}{|c|c|c|c|}
\hline Gender & $\begin{array}{c}\text { Group A } \\
(n=40)\end{array}$ & $\begin{array}{c}\begin{array}{c}\text { Group B } \\
(n=40)\end{array} \\
\end{array}$ & \\
\hline Male & $19(47.5 \%)$ & $15(37.5 \%)$ & 36 \\
\hline Female & $21(52.5 \%)$ & $25(62.5 \%)$ & \\
\hline Total & 40 & 40 & \\
\hline
\end{tabular}

After statistical analysis using chi square test, there was no statistical difference $(p>0.05)$ found between the groups and the sex distribution between the two groups were comparable ( Table 3 , figure 2.) 



Figure 2 Gender Distribution

Table: 4 Weight Distribution of Patients Studied

\begin{tabular}{|c|c|c|c|}
\hline Weight(kg) & $\begin{array}{c}\text { Group } \\
\mathbf{A}(\mathbf{n}=\mathbf{4 0})\end{array}$ & $\begin{array}{c}\text { Group } \\
\text { B(n=40) }\end{array}$ & \multirow{5}{*}{$\begin{array}{c}\text { P value } \\
0.708\end{array}$} \\
\hline $35-50$ & $17(42.5 \%)$ & $15(37.5 \%)$ & \\
\hline $51-60$ & $14(35 \%)$ & $21(52.5 \%)$ & \\
\hline $61-70$ & $09(22.5 \%)$ & $04(10 \%)$ & \\
\hline Mean \pm SD & $53 \pm 9.44$ & $52.25 \pm 8.35$ & \\
\hline
\end{tabular}



Figure-3: Weight Distribution

Weight in the two groups were statistically analyzed by student unpaired t test and it was found that there was no statistical difference between the two groups $\mathrm{p}>0.05$ ) (Tabel-4,Figure3)

Table : 5 Time to Induction (Seconds)

\begin{tabular}{|c|c|c|c|}
\hline $\begin{array}{c}\text { Time for } \\
\text { induction(sec) }\end{array}$ & $\begin{array}{c}\text { G roup A } \\
(\mathbf{n = 4 0 )}\end{array}$ & $\begin{array}{c}\text { G roup } \\
\mathbf{B}(\mathbf{n}=\mathbf{4 0})\end{array}$ & \\
\cline { 1 - 3 } P value \\
\cline { 1 - 3 }$<$ & 40 & 0 & \\
\hline$>100$ & 0 & 40 & \\
\hline Total & 40 & 40 & \\
\hline M ean \pm SD & $40.07 \pm 5.65$ & $158.85 \pm 21.9$ & \\
\hline
\end{tabular}

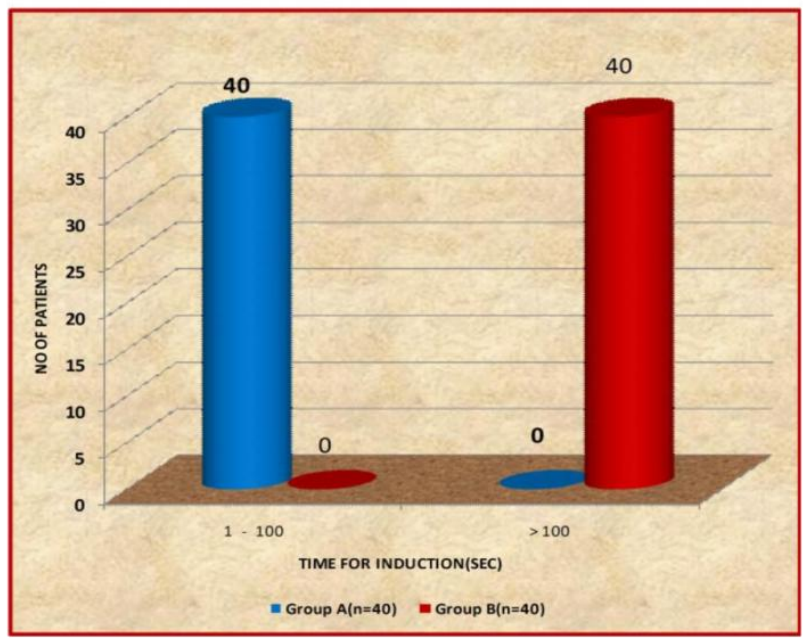

Figure-4: Time For Induction

Time to induction in seconds is significantly less in Group A (40.075 vs 158.85) with $\mathrm{P}<0.001$. (Table-5 and Figure-4)

Table: 6 Induction Side Effects

\begin{tabular}{|l|c|c|c|}
\hline $\begin{array}{l}\text { Induction side } \\
\text { effects }\end{array}$ & $\begin{array}{c}\text { Group A } \\
(\mathbf{n = 4 0 )}\end{array}$ & $\begin{array}{c}\text { Group B } \\
(\mathbf{n = 4 0 )}\end{array}$ & P value \\
\hline Breath holding & 3 & 0 & 0.077 \\
\hline Cough & 8 & 3 & 0.105 \\
\hline $\begin{array}{l}\text { Excitatory } \\
\text { movements }\end{array}$ & 4 & 1 & 0.166 \\
\hline Laryngospasm & 0 & 0 & \\
\hline Others & 0 & 0 & \\
\hline
\end{tabular}

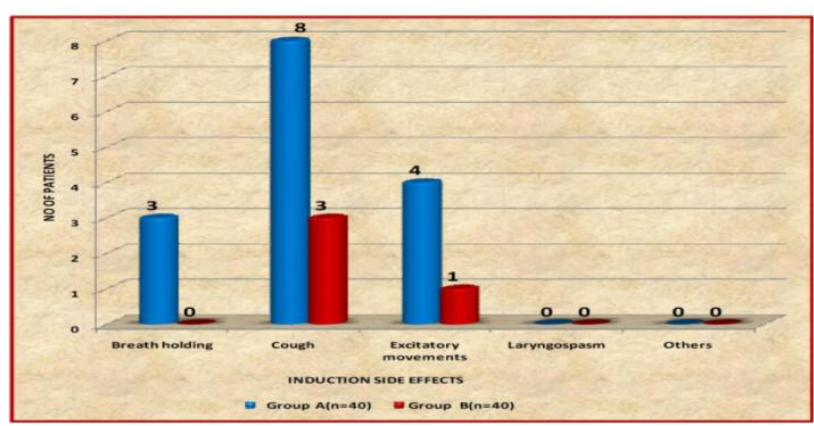

Figure-5: Induction Side Effects

Both groups were found to be statistically similar with respect to breath holding, cough, excitatory movements, laryngospasm and other induction side-effect.(Table-6 and Figure-5) 
Table: 7 Inter Group Comparison of Laryngoscopy, Vocal Cords Position, Vocal Cords Movement, Limb Movement And Coughing

\begin{tabular}{|c|c|c|c|c|}
\hline \begin{tabular}{|l} 
CCC \\
endotracheal \\
intubation \\
score
\end{tabular} & Criteria & $\begin{array}{c}\text { Group A } \\
(n=40)\end{array}$ & $\begin{array}{c}\text { Group B } \\
(n=40)\end{array}$ & $P$ value \\
\hline \multirow{3}{*}{ Laryngoscopy } & Easy & $26(65 \%)$ & $33(82.5 \%)$ & \multirow{3}{*}{0.094} \\
\hline & Fair & $11(27.5 \%)$ & $7(17.5 \%)$ & \\
\hline & Difficult & $3(7.5 \%)$ & $0(0 \%)$ & \\
\hline \multirow{3}{*}{$\begin{array}{ll}\text { Vocal } & \text { cords } \\
\text { position } & \end{array}$} & Abducted & $27(67.5 \%)$ & $33(82.5 \%)$ & \multirow{3}{*}{0.127} \\
\hline & Intermediate & $10(25 \%)$ & $7(17.5 \%)$ & \\
\hline & Closed & $3(7.5 \%)$ & $0(0 \%)$ & \\
\hline \multirow{3}{*}{$\begin{array}{l}\text { Vocal cords } \\
\text { movements }\end{array}$} & None & $27(67.5 \%)$ & $33(82.5 \%)$ & \multirow{3}{*}{0.088} \\
\hline & Moving & $9(22.5 \%)$ & $7(17.5 \%)$ & \\
\hline & Closing & $4(10 \%)$ & $0(0 \%)$ & \\
\hline \multirow{3}{*}{$\begin{array}{l}\text { Limb } \\
\text { movements }\end{array}$} & None & $20(50 \%)$ & $35(87.5 \%)$ & \multirow{3}{*}{0.001} \\
\hline & Slight & $11(27.5 \%)$ & $4(10 \%)$ & \\
\hline & Vigorous & $9(22.5 \%)$ & $1(2.5 \%)$ & \\
\hline \multirow{3}{*}{ Coughing } & None & $23(57.5 \%)$ & $35(87.5 \%)$ & \multirow{3}{*}{0.010} \\
\hline & $\begin{array}{c}\text { Diaphragmatic } \\
\text { movement }\end{array}$ & $12(30 \%)$ & $4(10 \%)$ & \\
\hline & $\begin{array}{c}\text { Severe } \\
\text { Coughing }\end{array}$ & $5(12.5 \%)$ & $1(2.5 \%)$ & \\
\hline \multirow{3}{*}{$\begin{array}{l}\text { Quality } \\
\text { intubation }\end{array}$} & Excellent & $17(42.5 \%)$ & $33(82.5 \%)$ & \multirow{3}{*}{0.001} \\
\hline & Good & $12(30 \%)$ & $4(10 \%)$ & \\
\hline & Poor & $11(27.5 \%)$ & $3(7.5 \%)$ & \\
\hline
\end{tabular}

Laryngoscopy was easy in $65 \%$ of patients in Group A and $83 \%$ in group B. The two groups were comparable with respect to laryngoscopy. ( $\mathrm{p}=0.094$, not significant). Regarding position of vocal cords, they were abducted in $66.7 \%$ of patients, intermediate in $26.7 \%$ and closed in $6.7 \%$ of patients in group A. In group B, vocal cords were abducted in $83.3 \%$ and intermediate in $16.7 \%$ of patients. The two groups were comparable with respect to vocal cord position. ( $\mathrm{p}=0.127$, not significant). Vocal cords were not moving in $66.7 \%$, moving in $23.3 \%$ and closing in $10 \%$ of patients in Group A. In Group B vocal cords were not moving in $83.3 \%$ and moving in $16.7 \%$ of patients. The two groups were comparable with respect to vocal cord movement. $(\mathrm{p}=0.088$, not significant) Limb movements were absent in $50 \%$, slight in $26.7 \%$ and vigorous in $23.3 \%$ patients in group A. In Group B $86.7 \%$ patients didn't move, $10 \%$ slightly moved, the remaining $3.3 \%$ of patients had vigorous movement. Patients in Group A had more limb movements than in Group B, which is significant. ( $\mathrm{p}=0.001$, highly significant). $56.7 \%$ of patients in group A had no coughing, while $30 \%$ patients had diaphragmatic movements and $13.3 \%$ had severe coughing after intubation. Group B patients had no coughing in $86.7 \%$, diaphragmatic movement in $10 \%$ and severe coughing in $3.3 \%$. Patients in group A had more coughing than in group B, which is significant. ( $\mathrm{p}=0.010$, significant).From the above studies, overall intubating conditions were significantly better in Group B than in Group A.
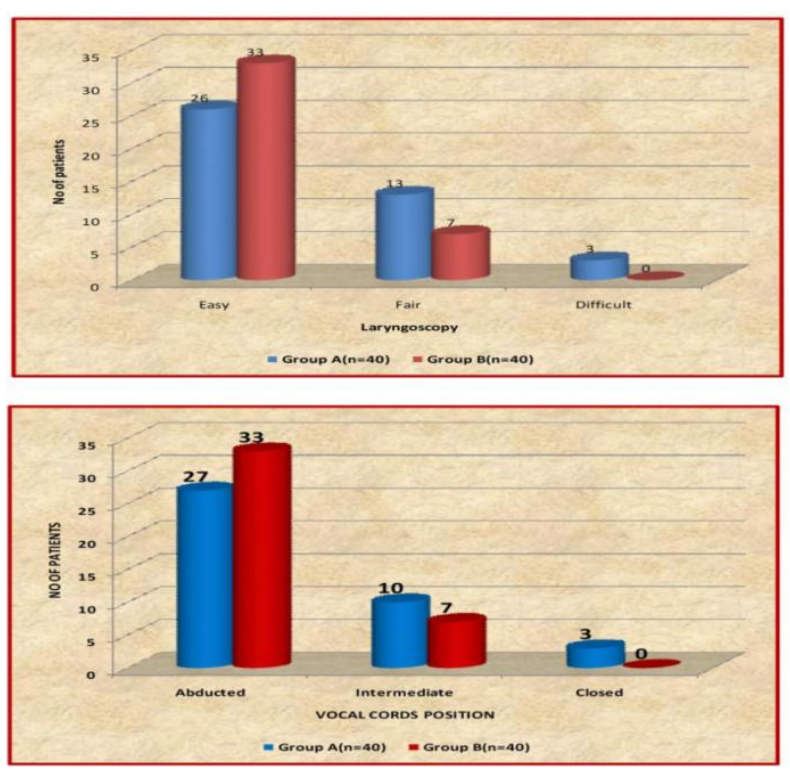

Figure-6 \& 7: Laryngoscopy and vocal cord position Respectively
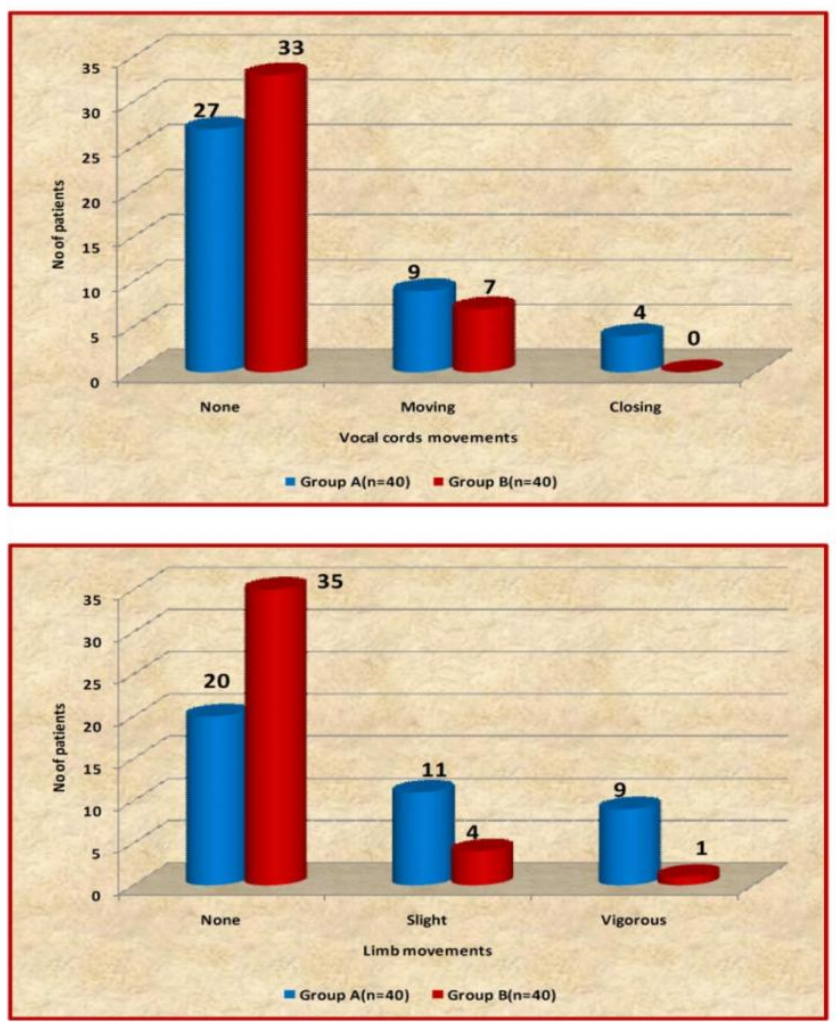

Figure: 8 \& 9 Vocal cord movement and Limb Movement 


\section{JMSCR Vol||07||Issue||03||Page 1419-1429||March}
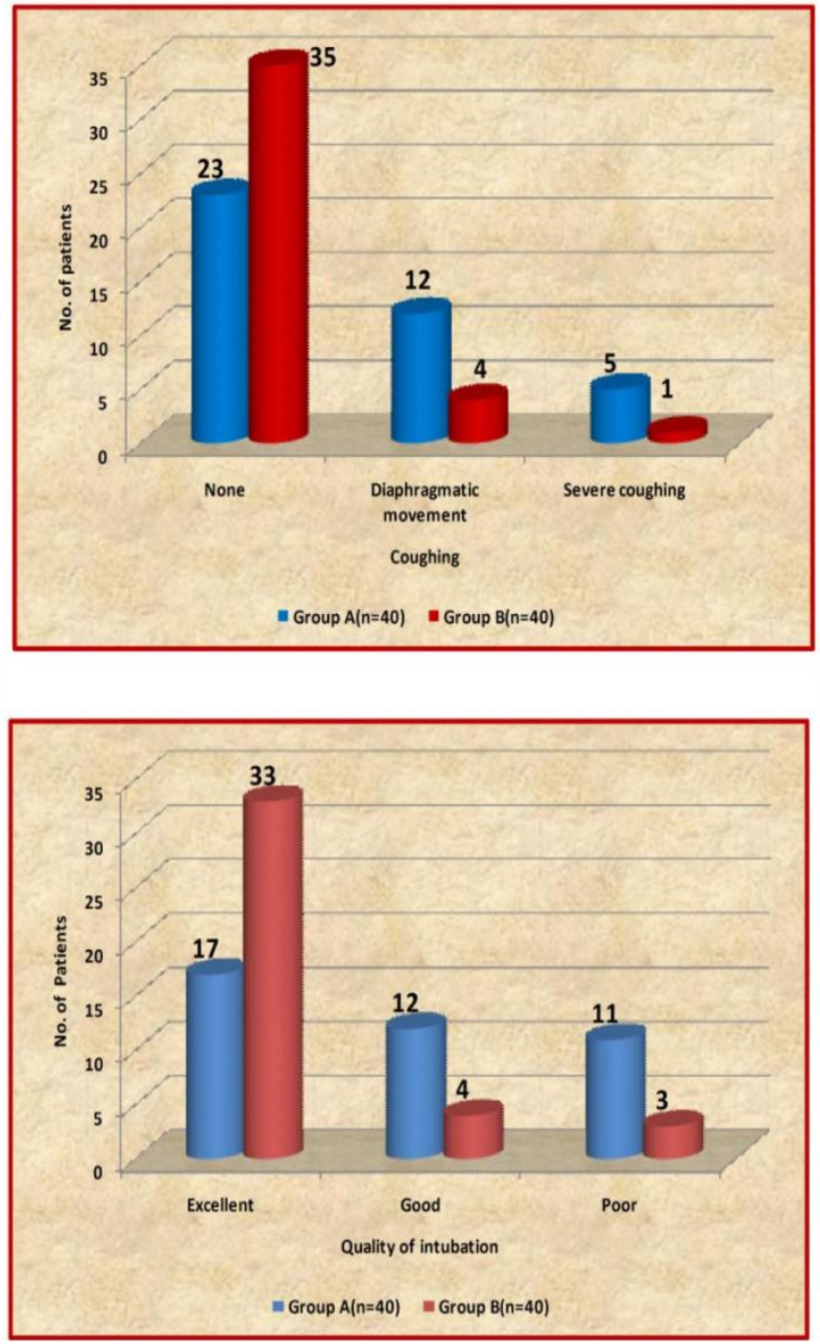

\section{Respectively}

Figure-10 \& Figure-11: Coughing and Quality of Intubatio Respectively

Table: 8 Overall Intubation Condition

\begin{tabular}{|l|c|c|c|}
\hline $\begin{array}{l}\text { Overall } \\
\text { intubation } \\
\text { condition }\end{array}$ & $\begin{array}{c}\text { Group } \\
\mathbf{A}(\mathbf{n}=\mathbf{4 0})\end{array}$ & $\begin{array}{c}\text { Group } \\
\mathbf{B}(\mathbf{n}=\mathbf{4 0})\end{array}$ & \\
\cline { 1 - 3 } Acceptable & $\begin{array}{c}29(72.5 \\
\%)\end{array}$ & $37(92.5 \%)$ & \multirow{2}{*}{$\mathbf{0 . 0 1 9}$} \\
\cline { 1 - 2 } $\begin{array}{l}\text { Unaccepta } \\
\text { ble }\end{array}$ & $\begin{array}{c}11(27.5 \\
\%)\end{array}$ & $03(7.5 \%)$ & \\
\hline
\end{tabular}

Overall acceptable intubating conditions were significantly associated with Group B when compared with Group A (92.5\% vs $72.5 \%)$ with $\mathrm{P}=0.019$ (Table- 8 and Figure-12)

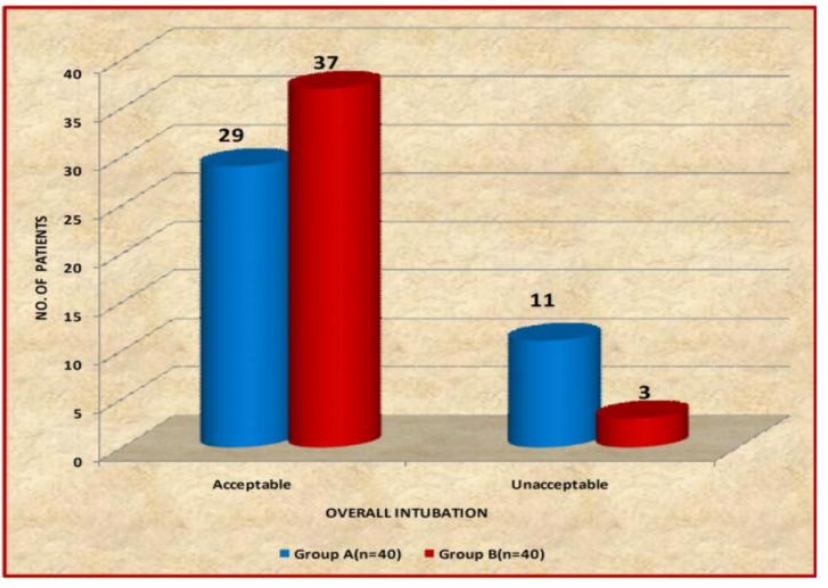

Figure12: Overall intubation

Table: 9 Number of Attempts

\begin{tabular}{|c|c|c|c|}
\hline $\begin{array}{c}\text { Number of } \\
\text { attempts }\end{array}$ & $\begin{array}{c}\text { Group } \\
\mathbf{A}(\mathbf{n}=\mathbf{4 0})\end{array}$ & Group $B(n=40)$ & \multirow{4}{*}{$\begin{array}{c}\text { P value } \\
0.016\end{array}$} \\
\hline 1 & $31(77.5 \%)$ & $39(97.5 \%)$ & \\
\hline 2 & $7(17.5 \%)$ & $1(2.5 \%)$ & \\
\hline 3 & $2(5 \%)$ & $0(0 \%)$ & \\
\hline
\end{tabular}

Number of attempts were significantly less in Group B when compared to Group A $(2.5 \%$ vs $22.5 \%$ ) with $\mathrm{P}<0.001$.(Figure-13 and Table-9)

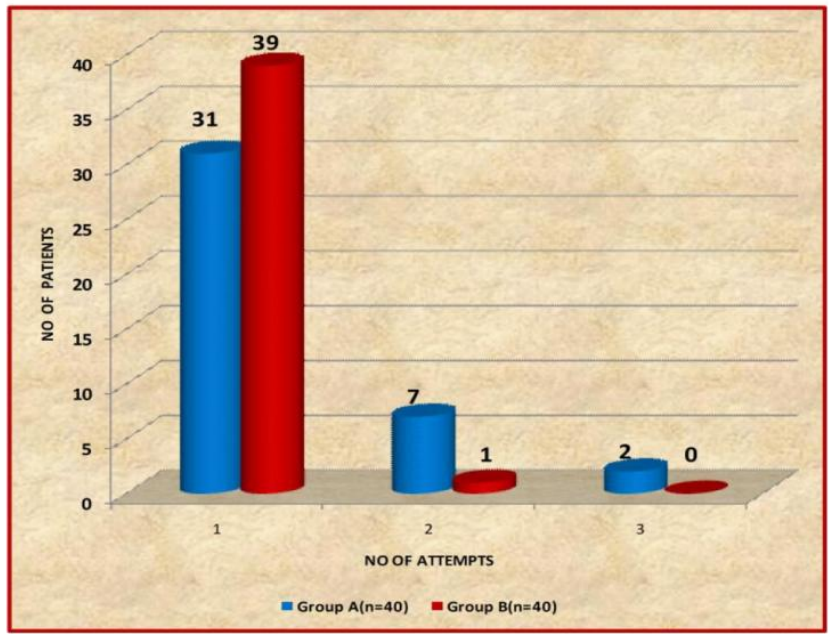

Figure-13: No. of Attempts

Table: 10 Tracheal Intubation Supplemented With Succinylcholine

\begin{tabular}{|l|c|c|c|}
\hline $\begin{array}{l}\text { Tracheal intubation } \\
\text { supplemented with } \\
\text { succinylcholine }\end{array}$ & $\begin{array}{c}\text { Group A } \\
(\mathbf{n = 4 0 )}\end{array}$ & $\begin{array}{c}\text { Group B } \\
(\mathbf{n = 4 0 )}\end{array}$ & $\begin{array}{c}\text { P value } \\
0.166\end{array}$ \\
\cline { 1 - 3 } No & $35(87.5 \%)$ & $40(100 \%)$ & \\
\hline Yes & $5(12.5 \%)$ & $0(0 \%)$ & \\
\hline
\end{tabular}

None of the patients in Group B required succinylcholine supplementation to achieve intubation, when compared with $12.5 \%$ in Group $\mathrm{A}$, which is not significant $(\mathrm{p}=0.166)$ (Table-10 


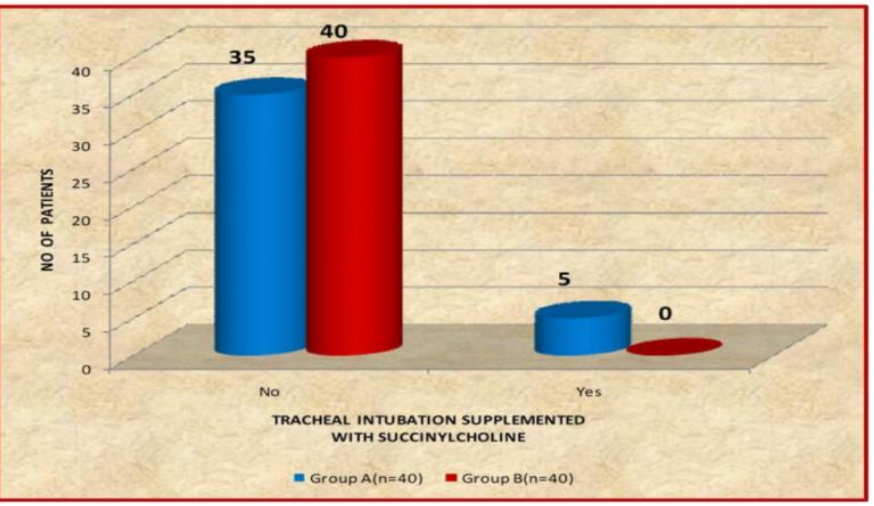

Figure-14: Tracheal Intubation Supplemented With Succinylcholine

Table :11 Comparison of Heart Rate (BPM) Between two Groups

\begin{tabular}{|l|c|c|c|}
\hline Time interval & $\begin{array}{c}\text { Group A } \\
(\text { Mean } \pm \text { SD) }\end{array}$ & $\begin{array}{c}\text { Group B } \\
(\text { Mean } \pm \text { SD) }\end{array}$ & P-value \\
\hline Pre induction & $90.175 \pm 9.28$ & $88.32 \pm 12.19$ & 0.447 \\
\hline $\begin{array}{l}\text { Post induction } \\
\text { inin after } \\
\text { intubation }\end{array}$ & $81.6 \pm 8.43$ & $85.32 \pm 11.93$ & 0.111 \\
\hline $\begin{array}{l}\text { 3 min after } \\
\text { intubation }\end{array}$ & $86.15 \pm 7.94$ & $90.47 \pm 12.09$ & 0.15 \\
\hline $\begin{array}{l}\text { 5 min after } \\
\text { intubation }\end{array}$ & $86.975 \pm 7.53$ & $88.82 \pm 11.68$ & 0.402 \\
\hline
\end{tabular}

There was no significant difference in heart rate after induction and post-intubation between the two groups except $3 \mathrm{~min}$ after intubation which was significant $(\mathrm{p}=0.032)$

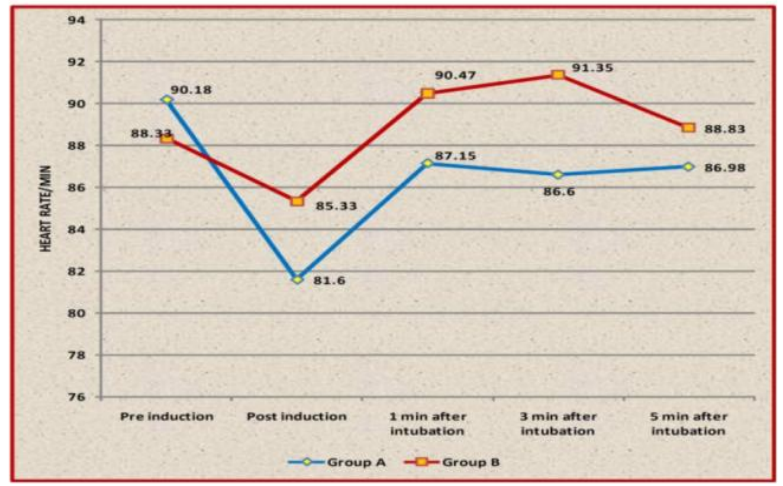

Figure-15: Comparision of Heart Rate

Table: 12 Comparison of SBP (mm hg) between two groups

\begin{tabular}{|l|c|c|c|}
\hline Time interval & $\begin{array}{c}\text { Group A } \\
(\text { Mean } \pm \text { SD) }\end{array}$ & $\begin{array}{c}\text { Group B } \\
(\text { Mean } \pm \text { SD })\end{array}$ & P value \\
\hline Pre induction & $124.15 \pm 9.35$ & $122.35 \pm 9.08$ & 0.385 \\
\hline Post induction & $109.47 \pm 9.29$ & $119.47 \pm 9.44$ & $<\mathbf{0 . 0 0 1}$ \\
\hline $\begin{array}{l}\text { min after } \\
\text { intubation }\end{array}$ & $118.32 \pm 8.47$ & $125.05 \pm 8.77$ & $\mathbf{0 . 0 0 1}$ \\
\hline $\begin{array}{l}\text { 3 min after } \\
\text { intubation }\end{array}$ & $119.9 \pm 8.55$ & $123.95 \pm 8.10$ & $\mathbf{0 . 0 3 2}$ \\
\hline $\begin{array}{l}\text { 5 min after } \\
\text { intubation }\end{array}$ & $117.57 \pm 7.62$ & $123.22 \pm 8.91$ & $\mathbf{0 . 0 0 3}$ \\
\hline
\end{tabular}

There was a significant difference in systolic blood pressure after induction and post-intubation at $1,3 \& 5 \mathrm{~min}$ between the two groups $(\mathrm{p}<0.001$, $\mathrm{p}=0.001, \mathrm{p}=0.032, \mathrm{p}=0.003$ respectively. (Table -12 and Figure-16)

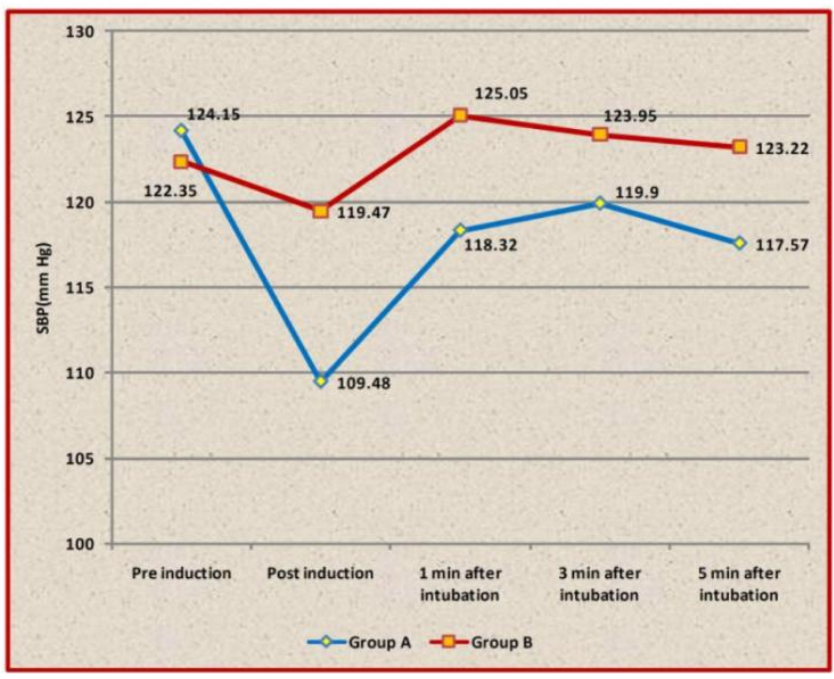

Figure-16: Comparison of SBP

Table: 13 Comparison of DBP ( $\mathrm{mm} \mathrm{hg}$ ) between two groups

\begin{tabular}{|l|c|c|c|}
\hline Time interval & $\begin{array}{c}\text { Group A } \\
(\text { Mean } \pm \text { SD })\end{array}$ & $\begin{array}{c}\text { Group B } \\
(\text { Mean } \pm \text { SD) }\end{array}$ & P value \\
\hline Pre induction & $82.1 \pm 7.96$ & $78.72 \pm 7.87$ & 0.060 \\
\hline $\begin{array}{l}\text { Post induction } \\
\text { min after } \\
\text { intubation }\end{array}$ & $73.07 \pm 8.19$ & $74.92 \pm 8.15$ & 0.314 \\
\hline $\begin{array}{l}\text { 3 min after } \\
\text { intubation }\end{array}$ & $81.85 \pm 8.97$ & $80.17 \pm 7.66$ & 0.372 \\
\hline $\begin{array}{l}5 \text { min after } \\
\text { intubation }\end{array}$ & $79.95 \pm 8.38$ & $78.6 \pm 7.66$ & 0.454 \\
\hline
\end{tabular}

There was no significant difference in diastolic blood pressure between the two groups following induction and intubation.(Table-13 and Figure-17)

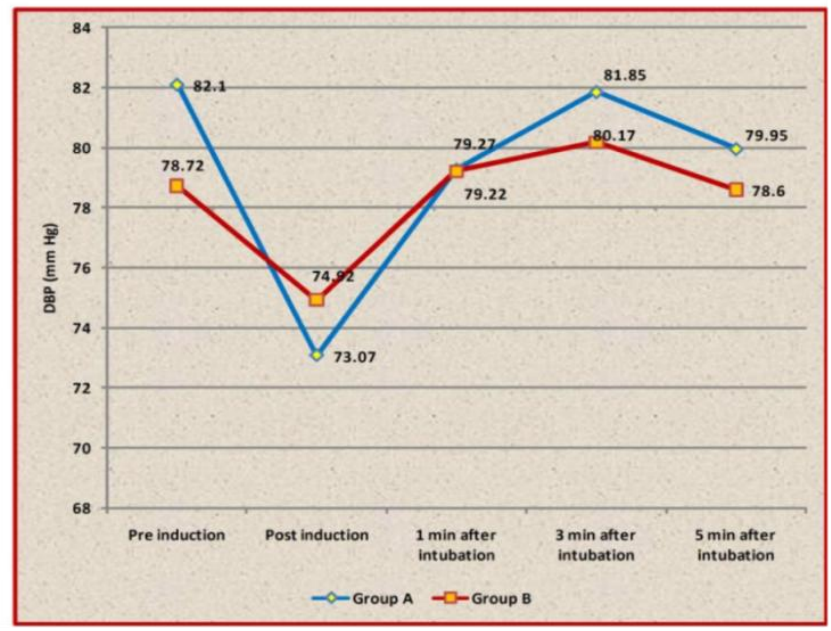

Figure-17 Comparison of DBP 
Table: 14 Comparison of Map (mm hg) between two groups

\begin{tabular}{|l|c|c|c|}
\hline Time interval & $\begin{array}{c}\text { Group A } \\
(\text { Mean } \pm \text { SD) }\end{array}$ & $\begin{array}{c}\text { Group B } \\
(\text { Mean } \pm \text { SD) }\end{array}$ & P value \\
\hline Pre induction & $95.9 \pm 7.88$ & $93.3 \pm 7.12$ & 0.125 \\
\hline $\begin{array}{l}\text { Post induction } \\
\text { 1 min after } \\
\text { intubation }\end{array}$ & $85.45 \pm 7.95$ & $89.87 \pm 7.32$ & $\mathbf{0 . 0 1 1}$ \\
\hline $\begin{array}{l}\text { 3 min after } \\
\text { intubation }\end{array}$ & $94.47 \pm 7.95$ & $94.77 \pm 6.81$ & 0.856 \\
\hline $\begin{array}{l}5 \text { min after } \\
\text { intubation }\end{array}$ & $92.52 \pm 7.49$ & $93.52 \pm 6.78$ & 0.533 \\
\hline
\end{tabular}

There was no significant difference in mean arterial pressure between the two groups following intubation, but there was a significant difference in mean arterial pressure following induction ( $p=0.011)$. (Table-14 and Figure-18)

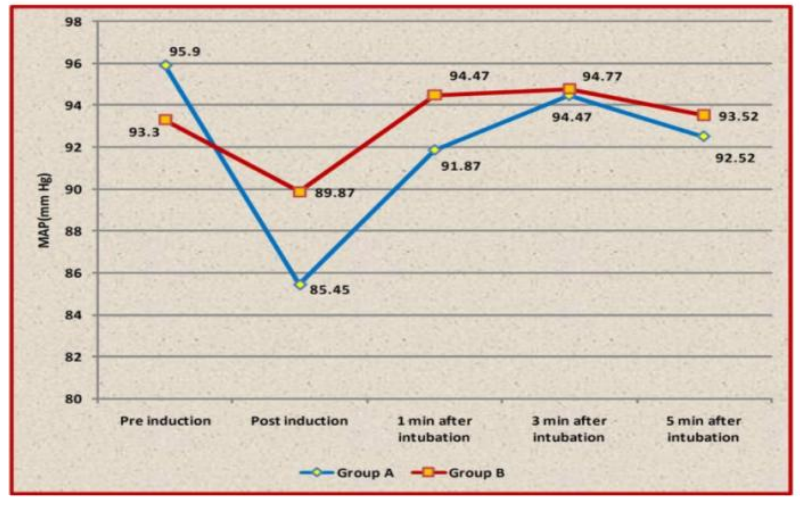

Figure-18: Comparison of Map

\section{Discussion}

For successful intubation the drugs should be combined in such a way that it produces unconsciousness, analgesia and muscle relaxation without compromising hemodynamic stability. ${ }^{7}$ Usually a combination of hypnotic agent, opioid and a neuromuscular blocking agent is used.

Sevoflurane a new inhalational agent with low blood-gas solubility and a relatively pleasant odour produces rapid induction and recovery. It causes less myocardial depression and cardiac arrhythmias than halothane.

The present study was carried out to assess tracheal intubating conditions and hemodynamic changes after induction of anaesthesia without the use of neuromuscular blocking drugs. Out of 80 patients, 40 received sevoflurane \& propofol and 40 received only propofol.

We took 240 s as a fixed time interval from the start of induction to intubation in Group A patients (IV propofol $3 \mathrm{mg} / \mathrm{kg}$ ). The use of fixed time interval tests an easily reproducible technique, independent of subjective assessments of depth of anaesthesia.

In Group B patients (4\% sevoflurane with IV propofol $1.5 \mathrm{mg} / \mathrm{kg}$ ), we chose to evaluate tracheal intubating conditions $240 \mathrm{~s}$ after the start of induction. There is lack of reliable end points. Depth of anaesthesia is also difficult to assess clinically, with some anaesthesiologists using clinical indications such as constriction and centralization of pupils, and acceptance of face mask, while others have found eye signs unreliable. Swadia VN et $\mathrm{al}^{20}$ and Bithal PK et $\mathrm{al}^{19}$ had found significantly greater time for tracheal intubation with sevoflurane i.e. $(242.2 \pm 52.67 \mathrm{~s})$ and $(325.93 \pm 44.02 \mathrm{~s})$ respectively. This difference was not only because of different clinical end points but also a different induction technique in which sevoflurane concentration was increased incrementally and ventilation was not assisted manually.

In present study, tracheal intubation was accomplished in $87.5 \%$ of patients in Group A, only $72.5 \%$ of those patients had acceptable intubating conditions and remaining $27.5 \%$ of patients had unacceptable intubating conditions. Three factors made the intubating scores unacceptable were vocal cords movement (32.5\%), coughing (42.5\%) and limb movements $(50 \%)$.

In Group A, laryngoscopy was easy in $65 \%$, fair in $27.5 \%$ and difficult in $7.5 \%$ of patients and vocal cords were moving in $22.5 \%$ and closing in $10 \%$ of patients, which is not significant. $12.5 \%$ of patients required succinylcholine supplementation to achieve intubation because of vocal cords movement, coughing and excessive limb movements. Only $76.7 \%$ of patients intubated at first attempt and remaining 23.3\% required multiple attempts.

During induction, $7.5 \%$ of patients in Group A had breath holding, 20\% had cough and $10 \%$ had excitatory movements, which is not significant. Induction time in Group A patients were 
$40.07 \pm 5.65$

In our study, tracheal intubation was accomplished in $100 \%$ of patients in Group B, $92.5 \%$ of those patients had acceptable intubating conditions when compared with $72.5 \%$ in Group $\mathrm{A}$, which is highly significant $(\mathrm{p}<0.001)$. In Group B, laryngoscopy was easy in $82.5 \%$ and fair in $17.5 \%$ of patients and vocal cords were abducted in $82.5 \%$ and moving in $17.5 \%$ of patients, which is not significant.

$87.5 \%$ of patients had no cough in Group B, compared with $57.5 \%$ in group A. Coughing was significantly associated more with Group A $(p=0.037) .10 \%$ of patients in Group B had diaphragmatic movements and $2.5 \%$ had severe coughing. Limb movements were absent in $87.5 \%$ of patients in Group B compared to 50\% in Group A. Limb movements were significantly more in Group A ( $\mathrm{p}=0.010) .10 \%$ of patients in Group B had slight and $2.5 \%$ had vigorous limb movements.

None of the patients in Group B required succinylcholine supplementation to achieve intubation. $97.5 \%$ of patients were intubated at first attempt in Group B when compared with $77.5 \%$ in Group A. Number of attempts were significantly less in Group B $(\mathrm{p}<0.001)$.

During induction in Group B patients $7.5 \%$ had cough and $2.5 \%$ had excitatory movements, which is not significant. Induction time in Group B patients were $158.85 \pm 21.91 \mathrm{~s}$, when compared with Group A (40.07 \pm 5.65$)$. Induction time were significantly more in Group B patients $(\mathrm{p}<0.001)$. In present study there was definite reduction in heart rate, systolic blood pressure, diastolic blood pressure and mean arterial pressure in Group A patients after induction and intubation when compared with pre-induction values. However, there was no significant difference among these parameters when compared with pre-induction values in Group B patients. Thus propofol decreased both heart rate and blood pressure, which indicates there was decrease in cardiac output. So propofol effectively attenuated the hemodynamic response to intubation.
The decrease in HR and blood pressure in our sudy was due to synergistic effects of fentanyl and propofol. Fentanyl blunted hemodynamic response to laryngoscopy and intubation whereas propofol decreased sympathetic nervous activity. In our study, there was no significant difference in heart rate after induction and intubation between the two groups, except $3 \mathrm{~min}$ after intubation, where, heart rate is significantly low in Group A (86.6 \pm 7.12$)$ when compared with Group B (91.35 \pm 11.84$),(\mathrm{p}=0.033)$.

There was significant reduction in systolic blood pressure after induction and intubation in Group A patients when compared with Group B patients. However, there was no significant difference in diastolic blood pressure and mean arterial pressure between two groups, except mean arterial pressure being significantly low in Group A following induction $(p=0.011)$. In Bithal PK et $\mathrm{al}^{19}$ study,HR was significantly high in the sevolurane group,during post induction, immediate post intubation and $1 \mathrm{~min}$ post intubation.MAP also increased but slightly from baseline.

\section{Conclusion}

To summarize, intubation without muscle relaxants using combination of inhalational $4 \%$ Sevoflurane with IV Propofol $1.5 \mathrm{mg} / \mathrm{kg}$ had more acceptable intubating conditions when compared with patients who received IV Propofol $3 \mathrm{mg} / \mathrm{kg}$.

\section{References}

1. Woods AW, Allam S. Tracheal intubation without the use of neuromuscular blocking agents. Br J Anaesth 2005; 94: 150-158.

2. Srivastava U, Kumar A, Gandhi NK, Saxena S, Agarwal S. Comparison of propofol and fentanyl with thiopentone and suxamethonium for tracheal intubation in children. Ind J Anaesth 2001; 45: 263-266.

3. Steyn MP, Quinn AM, Gillespie JA, Miller DC, Best CJ, Morton NS. Tracheal intubation without neuromuscular block in children. $\mathrm{Br} \mathrm{J}$ Anaesth 1994; 72: 403-406.

4. Akhilesh Gupta, Ranvinder Kaur, Rohit 
Malhotra, Suniti Kale. Comparative evaluation of different doses of propofol preceded by fentanyl on intubating conditions and pressor response during tracheal intubation without muscle relaxants. Paediatric Anaesthe 2006; 16: 399-405.

5. Robinson AL, Jerwood DC, Stokes MA. Routine suxamethonium in children. Anesthesia 199651 (9): 874 -78

6. Scheller MS, Zornow MH, Saidman LJ. Tracheal intubation without the use of musclerelaxants: a technique by using propofol and varying doses of alfentanyl.Anesth. Analg 1992 ; 75(5) 788 93

7. Francois D. Tracheal intubation: unconsciousness, analgesia and muscle relaxation. Can J Anesth 2003; 50: 99-103.

8. Hannallah RS, Britton JT, Schafer PG, Patel RI, Norden JM. Propofol anaesthesia in paediatric ambulatory patients: A comparison with thiopentone and halothane. Can J Anaesth 1994; 41: 12-18.

9. Abdel-Halim JMK, Azer MS, El-Awady GA. Comparison of induction and recovery characteristics of sevoflurane, halothane and propofol in pediatric outpatients. Journal of the Egyptian Nat. Cancer Inst 2002; 14: 319323.

10. Politis GD, Tobin JR,Morell RC, James RL, Cantwell MF.Tracheal intubation of healthy pediatric patients without muscle relaxants : a survey of technique utilization and perceptions of safety.Anesth.Analg 1999;88(4): 733 -4.

11. Politis GD, Frankland MJ,James RL,Reville JF ,Ricker MP,Petree BC.Factors associated with successful tracheal intubation of children with sevoflurane and no muscle relaxants.Anesth. Analg 2002;95(3): 615 - 20

12. Simon L, Boucebci KJ, Orliaquet G, Aubineau JV,Devys JM, Dubousset AM.A survey of practice of tracheal intubation without muscle relaxant in pediatric patients.

Pediatric Anesthesia 2002;12(1):36 - 42

13. Muzi M,Robinson BJ,Ebert TJ,O'Brien TJ.Induction of anesthesia and t ra ch ea 1 in tu ba $t$ io $n$ wi th $s$ ev of 1 ur an e in a du lt $\mathrm{s}$ .A ne st he si ol og y 1996;85(3):536 - 43

14. Hansen D, Schaffartzik W, Dopjans D, Heitz E, Striebel HW. Halothane- propofol anaesthesia for tracheal intubation in young children. Br J Anaesth1997; 78: 366-369.

15. Jellish WS, Lien CA, Fontenot HJ, Hall R. The comparative effects of sevoflurane versus propofol in the induction and maintenance of anesthesia in adult patients. Anesth Analg 1996; 82: 479-485.

16. Thwaites AJ, Edmends S, Tomlinson AA, Kendall JB, Smith I. Double-blind comparison of sevoflurane vs propofol and succinylcholine for tracheal intubation in children. Br J Anaesth 1999; 83: 410-414.

17. Sayyid SMS, Aouad MT, Taha SK, Daaboul DG, Deeb PG, Massouh FM, Muallem MRA, Baraka AS. A comparison of sevofluranepropofol versus sevoflurane or propofol for laryngeal mask airway insertion in adults. Anesth Analg 2005; 100: 1204-1209.

18. Coates D, Prys-Roberts C, Spelina K: Propofol (Diprivan) by intravenous infusion with nitrous oxide: Dose requirements and hemodynamic effects. Postgrad Med J 1985; 61:76.

19. Pramod Kumar Bithal, Atlaf Soudagar, Mallika Paul, Ayham Bali. Comparison of halothane with sevoflurane inhalation in children for tracheal intubation. Ind J Anaesth 2000; 44: 47-54.

20. Swadia VN, Mamta GP. Comparison of induction and of sevoflurane and halothane in paediatric patients. Ind J Anaesth 2001; 45(4): 294-297. 